PIOTR BYLICA

\title{
CLIVE'A S. LEWISA ARGUMENT Z PRAGNIEŃ PRZECIWKO NATURALIZMOWI
}

\begin{abstract}
Streszczenie. W artykule przedstawione zostaną różne sformułowania argumentu z pragnień, wysuniętego przeciwko naturalizmowi, autorstwa Clive'a S. Lewisa. Analizie zostaną poddane zarzuty o brak logicznej poprawności jego wywodu oraz dotyczące zwodniczego charakteru czynników irracjonalnych, do jakich zaliczają się uczucia i pragnienia. Wykazane zostanie, że sformułowania, w których mamy do czynienia z brakiem konkluzywności antynaturalistycznego wniosku Lewisa, można jednak traktować jako poznawczo wartościowe, gdyż są one oparte na indukcyjnym schemacie wnioskowania. Istnieją natomiast sformułowania, które jedynie wielkim kosztem, jakim jest uznanie Wszechświata za absurdalny, można uznać za niekonkluzywne. Podejrzenie, iż odwołanie do czynników irracjonalnych osłabia argumentację Lewisa, okazuje się błędne.
\end{abstract}

Słowa kluczowe: Clive S. Lewis; naturalizm; teizm; argument z pragnień

1. Wprowadzenie. 2. Antynaturalistyczny charakter argumentacji Lewisa. 3. Potrzeby wrodzone oraz ich zaspokajanie. 4. Zarzut pierwszy: zwodniczy charakter pragnień. 5. Zarzut drugi: problem prawdziwości przesłanek. 6. Zakończenie.

\section{WPROWADZENIE}

Czynniki irracjonalne, w tym uczucia i nastroje, mogą odgrywać pewną, a nierzadko znaczącą rolę w poznaniu, szczególnie gdy chodzi o sprawy, co do których rozum nie daje zadowalających wyników. Do tego faktu odwoływał się także śp. ks. prof. Grzegorz Bugajak podczas jednego ze swych ostatnich wystąpień konferencyjnych, które miało miejsce w czasie panelu Sekcji Filozofii Przyrody i Nauk Przyrodniczych Polskiego Towarzystwa Filozoficznego, jaki odbył się 13 września 2019 roku w Lublinie w Katolickim Uniwersytecie Lubelskim Jana Pawła II w ramach 11 Polskiego Zjazdu Filozoficznego. Przystępując do prezentacji swojej tezy monistycznej, mającej 
godzić naturalizm z nadnaturalizmem, czyli opcje filozoficzne pod względem logicznym (przynajmniej prima facie) wzajemnie sprzeczne, Grzegorz Bugajak stwierdził, że nie będzie niczego dowodził, ale swym wystąieniem postara się przedstawić pewne tropy, za pomocą których chce „uwieść" słuchaczy. Chciał więc wywołać u nich stan emocjonalny, który pozwoli im stwierdzić, że te dwa stanowiska można jakoś połączyć. Odwołanie do czynników irracjonalnych, takich jak uczucia, nastroje i pragnienia, można jednak wykorzystać także w przesłankach argumentacji na rzecz jakichś przekonań. $\mathrm{Na}$ tej zasadzie ks. Bugajak we wspomnianym wystąpieniu odwoływał się do fragmentów Biblii, na podstawie których wnioskował, że według proroka Izajasza to nie rozumowanie, a uwodzenie jest sposobem, w jaki rzeczywistość nadnaturalna wpływa na człowieka ${ }^{1}$.

W niniejszym tekście przyjrzymy się klasycznemu już argumentowi Clive'a S. Lewisa przeciwko monizmowi naturalistycznemu. Lewis, podobnie jak ks. prof. Bugajak we wskazanych wyżej wypowiedziach, odwoływał się do czynnika irracjonalnego w człowieku, mianowicie do pragnień i szczególnego uczucia radości. Dla uproszczenia argument ten będzie określany mianem ,argumentu z pragnień". Przy tej okazji rozważymy też, czy ze względu na oparcie wywodu na odwołaniu do czynników irracjonalnych argument ten nie przynosi więcej szkody niż pożytku w dążeniu do uzasadnienia prawdziwości teizmu. Przyjrzymy się więc zwodniczemu charakterowi tego typu czynników.

Choć w wersji, jaką tu przedstawimy, argument z pragnień pochodzi od Lewisa, to występował jednak już wcześniej w średniowiecznej myśli teologicznej Augustyna z Hippony, Grzegorza z Nyssy, Anzelma z Canterbury czy Bernarda z Clairvaux. Pisali oni o duchowej tęsknocie, niezaspokojonym pragnieniu, które może zaspokoić tylko

1 Zapis video tego wystąpienia znajduje się na stronie internetowej SFPiNP: https://www. filozofiaprzyrody.pl/naturalizm-nadnaturalizm-panel-dyskusyjny/, [dostęp 9.2020]. 
Bóg. Mówili też o Bogu jako źródle tego pragnienia². Wyznania św. Augustyna zawierają jeden z najbardziej znanych w myśli chrześcijańskiej przykładów odwołania do szczególnego pragnienia, jakim jest pragnienie Boga. Augustyn wyznawał tam z żalem: „(...) nie w Bogu, lecz w Jego stworzeniach, w sobie i w innych, szukałem radości, wzniosłości i prawdy. Tak zapadłem w cierpienia, w pomyłki, w błędy"3. W końcu jednak rozpoznał, że tym, czego naprawdę pragnął, był Bóg i pod koniec życia sformułował słynne słowa: „Stworzyłeś nas bowiem jako skierowanych ku Tobie. I niespokojne jest serce nasze, dopóki nie spocznie w Tobie"4. Rozumowanie Lewisa wpisuje się też w nurt myśli Platona, według którego wszystko, co spotykamy w świecie i traktujemy jako dobro, czyli coś wartego pożądania, pochodzi ostatecznie od Idei Dobra, istniejącej poza tym światem, a celem człowieka jest poznanie samego Dobra.

\section{ANTYNATURALISTYCZNY CHARAKTER ARGUMENTACJI LEWISA ${ }^{5}$}

Niektórzy uważają, że w przypadku rozumowania Lewisa miało być ono nie tyle argumentem na rzecz istnienia Boga, ile przede wszystkim przekonywać o istnieniu Nieba w sensie Raju, Zbawienia czy innego świata, w którym znajduje się zaspokojenie szczególnego pragnienia czy tęsknoty, które Lewis miał na myślib. W każdym

2 Zob. A. McGrath, The Intellectual World of C.S. Lewis, Wiley-Blackwell, Oxford 2014, 107-108.

3 Święty Augustyn, Wyznania, tłum. z łac. Z. Kubiak, Instytut Wydawniczy PAX, Warszawa 1987, 30 (1.20).

4 Tamże, 7 (1.1).

5 Ten punkt niniejszego artykułu został wcześniej w zbliżonej formie umieszczony przez autora w witrynie internetowej apologetyczno-edukacyjno-popularyzatorskiej i częściowo naukowej contragentiles.pl pod adresem: https://contragentiles.pl/glowne-dzialy/ teizm-chrzescijanski/argumenty-przeciwko-naturalizmowi-i-na-rzecz-istnienia-boga/ argument-z-pragnien-i-radosci/, [dostęp 9.2020]. Tytuł tekstu: Argument z pragnień i radości.

6 Zob. A. McGrath, The Intellectual World of C.S. Lewis, dz. cyt., 105. 
razie miał on jednak wykazywać, że pogląd naturalizmu, uznający, że istnieje tylko ten świat, nie daje się utrzymać.

W swych rozważaniach na temat pochodzenia i natury pragnień ludzkich Lewis odpowiadał na popularną koncepcję Zygmunta Freuda, głoszącą, że wszystkie ludzkie dążenia, skłonności i pragnienia mają ostatecznie charakter seksualny. Niezaspokojone pragnienia seksualne, dążenie do seksualnej przyjemności oraz lęk przed śmiercią miały być prawdziwym obliczem wszystkich innych pragnień, także religijnych, takich jak tęsknota do Boga, pragnienie nieśmiertelności, wiecznego szczęścia. Dla Freuda przekonanie o tym, że te religijne pragnienia miały być spełnione, było wyrazem szczególnego rodzaju iluzji, pobożnych życzeń: „Powiadamy sobie, że przecież pięknie by było, gdyby istniał Bóg jako stwórca świata i dobrotliwa Opatrzność, moralny ład świata i życie pozagrobowe, ale przecież rzuca się nam w oczy, że to wszystko tak wygląda, jak sobie tego życzymy"7.

Takie rozumienie pragnień i oczekiwań, występujących u ludzi religijnych, jest naturalistyczne w tym sensie, że odrzuca ideę nadnaturalnego źródła pochodzenia religii oraz tych oczekiwań. Wyjaśnia się je wyłącznie czynnikami z tego świata. Ostatecznie źródłem uczuć religijnych miałby być instynkt seksualny, który jest wspólny dla ludzi i zwierząt.

Lewis starał się wykazać, że sytuacja jest zupełnie odwrotna. Wszystkie pragnienia, także te erotyczne, są w rzeczywistości pragnieniem najwyższego Dobra. Natomiast ono samo nie jest $z$ tego świata. Pragnąc różnych rzeczy tego świata, faktycznie pragniemy czegoś, co jest jedynie, jak to określał Platon, cieniem czy odbiciem tego Dobra.

Lewis odwoływał się do pewnego wewnętrznego doznania, będącego zarówno pragnieniem, jak i radością. Jest ono także w pewnym sensie smutkiem i tęsknotą. W języku angielskim opisywał to

7 Z. Freud, Przyszłość pewnego złudzenia, w: Tenże, Kultura jako źródło cierpień, tłum. z niem. J. Prokopiuk, Aletheia, Warszawa 2013, 173. 
uczucie za pomocą słów joy oraz desire. W swojej autobiografii Lewis wspominal, jak pragnienie to pojawiało się w trakcie jego życia. Uznawał jednocześnie, że jest ono powszechnym doświadczeniem ludzkości. Następująco opisywał sytuacje, gdy się ono pojawiało: „(...) wszystkie te wydarzenia miały cechę wspólną: przynosiły ze sobą niezaspokojone pragnienie, które samo w sobie było godniejsze pożądania niż cokolwiek, co mogłoby je zaspokoić. Taki właśnie stan nazywam Radością. Określenie to należy potraktować jako pewien ścisły, techniczny termin - radość oznacza tu coś innego niż szczęście czy przyjemność. Łączy ją z nimi tylko jedno, a mianowicie to, że kto raz doświadczył Radości, będzie jej pragnął znowu. (...) należałoby raczej nazwać ją szczególnym rodzajem smutku lub przygnębienia. Jest to jednak smutek, za którym się tęskni. Wątpię, czy ktoś, kto go doświadczył, chciałby, gdyby to było w jego mocy, zamienić jedna chwilę Radości na wszystkie przyjemności świata. Radość jednak, inaczej niż przyjemność, nigdy nie zjawia się na zawołanie"8.

Lewis mówi o pragnieniu, którego żadna rzecz z tego świata nie może zaspokoić. Zdarza się jednak, że kontakt z rzeczami tego świata może spowodować, że pragnienie to się pojawi. Dlatego też wielu uznaje, że dążenie do zdobycia tych rzeczy da im zaspokojenie. Jest to jednak błędne myślenie, o czym nieustannie się przekonujemy. W życiu doczesnym skazani jesteśmy na ciągłe niezaspokojenie, uznając rzeczy tego świata za ostateczne dobro. Prawdziwe spełnienie daje bowiem jedynie Bóg, życie wieczne, wieczna radość, o jakiej mówi religia. A one nie są z tego świata. Rozumowanie Lewisa można przedstawić następująco:

Przesłanki: (1) Człowiek odczuwa pewne szczególne pragnienie, które samo jest wspaniałym doznaniem (Joy); (2) Ponieważ każde pragnienie jest pragnieniem czegoś, więc samo to pragnienie nie może być tym, co ma je zaspokajać; (3) Pragnienie to nie znajduje

8 C.S. Lewis, Zaskoczony radością. Moje wczesne lata, tłum. z ang. M. Sobolewska, Wydawnictwo Esprit, Kraków 2010, 30-31. 
zaspokojenia w żadnym skończonym obiekcie z tego świata; (4) Dla każdego pragnienia istnieje przedmiot, który jest $\mathrm{w}$ stanie je zaspokoić - natura niczego nie czyni na próżno.

Wniosek: Musi istnieć jakiś obiekt nieskończony, który może w pełni zaspokoić to pragnienie; tym obiektem jest Bóg, Zbawienie, Nieśmiertelność9.

W literaturze poświęconej Lewisowi dyskutuje się nad wartością dowodową jego argumentacji. Według McGratha rozumowanie Lewisa $z$ samego zamierzenia nie miało być dowodem logicznym. Jego wartość polega na tym, że pokazuje, iż obserwowane fakty pasują równie dobrze (jeśli nie lepiej) do chrześcijańskiej wizji rzeczywistości, a nie tylko do wizji naturalistycznej ${ }^{10}$. John Beversluis analizuje natomiast ten argument jako wywód logiczny i uznaje go za niekonkluzywny ${ }^{11}$. W dalszej części bliżej zajmiemy się zarzutami Beversluisa.

\section{POTRZEBY WRODZONE ORAZ ICH ZASPOKAJANIE}

Przebieg rozumowania argumentu odwołującego się do pragnień, można przedstawić na różne sposoby. Nieco inaczej niż we wcześniej przedstawionej formie prezentuje go Peter S. Williams, angielski filozof chrześcijański, w swojej książce C.S. Lewis vs the Nerw Atheists. Williams pokazuje tam, że to, co pisał Lewis, jest wciąż aktualne i doskonale nadaje się do obrony chrześcijaństwa przed atakami współczesnych wojujących ateistów ${ }^{12}$. Williams podaje i analizuje

9 P. Bylica, Rozum wobec żałoby: argumenty apologetyczne C.S. Lewisa w obliczu dotkliwej straty. Część I. Rozum, Przegląd Religioznawczy (2019)1, 139.

10 Zob. A. McGrath, The Intellectual World of C.S. Lewis, dz. cyt., 105-128.

11 Zob. J. Beversuis, C.S. Lewis and the Search for Rational Religion, William B. Eerdmans Publishing Company, Grand Rapids 1985, 33-69.

12 Zob. P.S. Williams, C.S. Lewis vs the New Atheists, Paternoster, Milton Keynes 2013. Znaczna część dalszego wywodu opiera się na tym opracowaniu. Przedstawione dalej zarzuty względem argumentacji Lewisa, które dotyczą zwodniczości uczuć, nie są jednak przez Williamsa w ogóle wymieniane ani analizowane. 
dwa sformułowania omawianej argumentacji. Pierwsze akcentuje wrodzony charakter pragnienia czy tęsknoty, o której pisał Lewis:

Przesłanka 1: Każde wrodzone pragnienie nakierowane jest na odpowiedni istniejący obiekt, który je zaspokaja.

Przesłanka 2: Mamy wrodzone pragnienia, które zaspokoić może tylko Bóg.

Wniosek: Zatem Bóg istnieje ${ }^{13}$.

Drugie sformułowanie też odwołuje się do wrodzonego charakteru tego pragnienia, ale w przesłankach odwołuje się do absurdalności wszechświata, z którą mielibyśmy do czynienia, gdyby nie istniały przedmioty, zaspokajające nasze wrodzone pragnienia. Drugie sformułowanie przedstawimy w dalszej części. Obecnie zajmiemy się pierwszym.

Powyższe rozumowanie opiera się na rozróżnieniu między pragnieniami, potrzebami (1) naturalnymi, wrodzonymi i (2) sztucznymi, nabytymi (dla uproszczenia wywodu nie będziemy tu rozróżniać między potrzebami i pragnieniami, które to rozróżnienie w psychologii może być uznawane za istotne; tu jednak tak nie jest). Do naturalnych, wrodzonych potrzeb i pragnień ludzi należą m.in: potrzeba jedzenia, picia, współżycia seksualnego, oddychania. Pragnienia nabyte to np. pragnienie: pieniędzy, nowego bmw, zdobycia mistrzostwa świata w piłce nożnej przez reprezentację Polski, zdolności, jakie miał główny bohater Matrixa, lotu na Marsa, zamieszkania w Narnii lub zostania bohaterem fikcyjnego świata Star Trek. Pierwsze z tych pragnień pochodzą z natury człowieka, a drugie są wynikiem życia w społeczeństwie, oglądania reklam, filmów, kontaktu z literaturą, sztuką itp. Gdyby nie istniało to, co zaspokaja pierwsze $z$ nich, to ludzie nie mogliby istnieć. Bez przedmiotów, zaspokajających drugi z tych rodzajów potrzeb, nasze istnienie dalej byłoby możliwe. Lewis podaje przykłady potrzeb naturalnych, jako argument na rzecz istnienia tego, co miałoby zaspokoić to szczególne pragnienie

13 Tamże, 63. 
(pragnienie Boga, zbawienia itd.): „Chrześcijanin stwierdza: „Żadna istota nie rodzi się z takim pragnieniem, dla którego nie istniałoby jakieś zaspokojenie«. Dziecko odczuwa głód - istnieje pożywienie. Kaczątko chce pływać - istnieje woda. Ludzie odczuwają pożądanie seksualne - istnieje seks. Skoro więc odnajduję w sobie pragnienie, którego nie może zaspokoić żadne doświadczenie na tym świecie, najprawdopodobniej oznacza to, że zostałem stworzony dla innego świata"14.

Na tej podstawie można wnioskować, że Lewis, mówiąc o pragnieniu Boga, ma na myśli wrodzoną potrzebę ludzką, którą posiadamy z natury. Ale także potrzeby nabyte są jego zdaniem podpowiedziami, wskazówkami, które mają kierować nas ku temu, co naprawdę jest naszym przeznaczeniem: „Jeśli mojego pragnienia nie zaspokajają żadne ziemskie przyjemności, wszechświat nie musi wcale być szalbierstwem. Zapewne ziemskie przyjemności od początku nie miały go zaspokajać, a tylko rozbudzać i wskazać na właściwy jego przedmiot. Skoro tak, z jednej strony muszę się starać nie gardzić ziemskimi błogosławieństwami i być za nie wdzięczy, a z drugiej nie mylić ich z tym czymś, czego są jedynie kopią, echem czy mirażem. Muszę pielęgnować w sobie tęsknotę za prawdziwą ojczyzną, której nie odnajdę aż do śmierci" 15 .

W rozumowaniu tym zakłada się więc, że człowiek ma wrodzone pragnienie Boga (które może jednak przejawiać się na różne sposoby w postaci pragnień rzeczy tego świata), oraz że każde wrodzone, naturalne pragnienie ma przedmiot, który je zaspokaja. Na rzecz tego, iż jest ono elementem natury ludzkiej, można argumentować, że spotyka się je wśród przedstawicieli różnych kultur, a nawet osób zadeklarowanych jako osoby niewierzące. Jest ono czymś, co

14 C.S. Lewis, Chrześcijaństwo po prostu, tłum. z ang. P. Szymczak, Media Rodzina, Poznań 2002, 24, 137. Zob. też P.S. Williams, C.S. Lewis vs the New Atheists, dz. cyt., 73.

15 C.S. Lewis, Chrześcijaństwo po prostu, dz. cyt., 137. Por. P.S. Williams, C.S. Lewis vs the New Atheists, dz. cyt., 73-74. 
kierowało nie tylko twórcami i wybitnymi przedstawicielami różnych religii, ale w wyraźny sposób występuje też u poetów i artystów, poszukujących absolutnego piękna i doskonałości. Williams wskazuje, że wielu ateistów również wyrażało pragnienie transcendencji. Friedrich Nietzsche napisał na temat Dantego i Spinozy, że „ich sposób myślenia w porównaniu z moim sprawiał, że [moja] samotność stawała się znośna; i ostatecznie dla każdego, kto w jakiś sposób wciąż miał »Boga« za towarzysza (...). Moje życie przepełnione jest obecnie pragnieniem, aby było odwrotnie, niż jawi się to memu pojmowaniu, i aby ktoś zdołał sprawić, że moje "prawdy» wydadzą mi się niedorzeczne"16. Z kolei Albert Camus wyraził się następująco: „dla człowieka, który jest sam, bez Boga i bez pana, ciężar dni jest straszliwy"17. Bruce Sheiman, amerykański ateista, autor książki Atheist Defends Religion, przyznaje: „Chcę wierzyć, że powód, dla którego my, skończone istoty, wyglądamy ku niewysłowionemu i niezgłębionemu Absolutowi jest taki, że jesteśmy Imago Dei. Chcę wierzyć, że nasze niekończące się dążenie do dobra i ku transcendencji ma swój punkt Omega w Bogu (...) mimo tego, że nie potrafię wierzyć w Boga, to wciąż odczuwam jego potrzebę"18. Nawet filozof Bertrand Russell, do którego spuścizny odwołują się dziś tzw. nowi ateiści, jak Richard Dawkins, pisał w jednym z listów, opublikowanych w jego autobiografii, o poszukiwaniu czegoś niewysłowionego, co nie daje się uchwycić i jednocześnie nie sprowadza się do niczego spotykanego w tym świecie, choć szukamy tego w rzeczach tego świata. One jednak nie dają zaspokojenia: „Wszystko, co mówimy, to bezowocne wysiłki, aby powiedzieć coś jeszcze - coś,

16 Cyt. za: P.S. Williams, C.S. Lewis vs the New Atheists, dz. cyt., 85 (The Portable Nietzsche, red. W. Kaufmann, Doubleday, New York 1954, 441).

17 A. Camus, Upadek, tłum. z fr. J. Guze, Warszawskie Wydawnictwo Literackie MUZA SA, Warszawa 1996, 113.

18 Cyt za: P.S. Williams, C.S. Lewis vs the New Atheists, dz. cyt., 86 (B. Sheiman, An Atheist Defends Religion: Why Humanity Is Better Off With Religion Than Without It, Alpha, New York 2009, ix). 
co zapewne $z$ samej swej natury nie może być powiedziane. Wiem, że przez całe życie usiłuję powiedzieć coś i nigdy się nie nauczę, jak to powiedzieć. (...) Tak jest ze wszystkimi, którzy spędzają życie na poszukiwaniu czegoś nieuchwytnego, a jednak wszechobecnego, subtelnego i zarazem nieskończonego. Szuka się tego w muzyce, morzu i zachodach słońca; czasami wydawało mi się, że jestem bardzo blisko tego w tłumie ludzi, kiedy czułem silnie to, co oni odczuwali; przede wszystkim szuka się tego w miłości. Jeśli jednak wyobrazimy sobie, że znaleźliśmy to, pojawi się na pewno okrutna ironia i wykaże nam, że naprawdę tak nie jest (...). Nawet kiedy czujemy się bardzo bliscy innym ludziom, wydaje się, że coś w nas uporczywie należy do Boga i nie chce wejść w ziemski związek - tak przynajmniej bym to wyraził, gdybym sądził, że jest Bóg. To dziwaczne, nieprawdaż? Jestem żarliwie przywiązany do tego świata i do wielu rzeczy, i do ludzi, a jednak... czym jest to wszystko? Czujemy, że musi być coś o wiele ważniejszego, chociaż nie wierzę, że jest"19.

Odczucia i tęsknota, o których pisał Lewis, okazują się więc nie być tylko jego osobistym przeżyciem, ale doświadczeniem znanym ludzkości, nawet tym ludziom, którym daleko jest do wiary w Boga.

\section{ZARZUT PIERWSZY: ZWODNICZY CHARAKTER PRAGNIEŃ}

Argumentacja Lewisa może rodzić (i rzeczywiście rodzi) różne zastrzeżenia. Jedno z najbardziej oczywistych nie znajduje bezpośredniej odpowiedzi w tekstach Lewisa, poświęconych argumentowi z pragnień. Jednak zarówno to, co pisał w innych miejscach, jak i w ogóle doktryna chrześcijańska wskazują na możliwą odpowiedź na zarzut, który mamy na myśli. Chodzi mianowicie o to, że należy uznać za dziwne, iż Bóg, który (jak przyjmuje chrześcijaństwo) stworzył człowieka i wpisał w jego naturę różne pragnienia, posłużył się

19 B. Russell, Autobiografia. Tom II - 1914-1944, tłum. z ang. A. Podzielna, Czytelnik, Warszawa 1998, 118-119. Zob. też P.S. Williams, C.S. Lewis vs the New Atheists, dz. cyt., 86. 
nimi, aby skierować człowieka ku Wieczności, Transcendencji, aby oderwać człowieka od rzeczy tego świata. To, co przywiązuje nas do tego świata, ma być jednocześnie wskazówką na istnienie rzeczywistości transcendentnej. Powtórzmy słowa Lewisa: „Jeśli mojego pragnienia nie zaspokajają żadne ziemskie przyjemności, wszechświat nie musi wcale być szalbierstwem. Zapewne ziemskie przyjemności od początku nie miały go zaspokajać, a tylko rozbudzać i wskazać na właściwy jego przedmiot. Skoro tak, z jednej strony muszę się starać nie gardzić ziemskimi błogosławieństwami i być za nie wdzięczy, a z drugiej nie mylić ich z tym czymś, czego są jedynie kopią, echem czy mirażem. Muszę pielęgnować w sobie tęsknotę za prawdziwą ojczyzną, której nie odnajdę aż do śmierci”20. Te „ziemskie błogosławieństwa”, czyli kopie lub miraże prawdziwego dobra, są jednak bardzo często przyczyną upadku poszczególnych ludzi, którym nie udaje się rozpoznać w nich tego, czym według Lewisa naprawdę są. Czyż uzależnienie od alkoholu, narkotyków, seksu itp. to nie typowe przykłady zabłąkania się w poszukiwaniu „prawdziwej ojczyzny”?

Lewis oczywiście zdawał sobie sprawę z tego zagrożenia, jakim jest niezorientowanie się co do prawdziwej natury pragnień. Swoją drogę życiową, polegającą na oddawaniu się rozmaitym namiętnościom, opisywał jako „błądzenie pielgrzyma” i pisał, że „(..) życie powinno się skupiać na wytrwałej wędrówce do tamtej ojczyzny i na pomocy udzielanej innym, którzy tam również zmierzają"21. Ludzie potrzebują pomocy w swoich poszukiwaniach, bo jeśli nie znajdą tej ojczyzny, to trafia gdzie indziej, czyli tam, gdzie lepiej jest dla człowieka nie trafić. Zagrożenie jest zatem realne.

Lewis zauważa też interesującą rzecz, że wbrew powszechnemu mniemaniu, najgroźniejszy nie jest wcale pociąg do niebezpieczeństw, takich jak alkohol, seks, pogoń za pieniędzmi, co do których każdy łatwo rozpoznaje ich zwodniczy charakter. W pewnym sensie

20 C.S. Lewis, Chrześcijaństwo po prostu, dz. cyt., 137.

21 Tamże, 138. 
poważniejsze są pomyłki dotyczące przedmiotów, które bardziej kojarzą się z tym, co słuszne, a nawet święte czy Boskie, bardziej przypominają Boga, będącego rzeczywistym celem. Jest tak na przykład z miłością, gdy uznajemy ją za cel sam w sobie, wartość najwyższą: „Słowa świętego Jana »Bóg jest miłością« stanowiły długo w moim umyśle jakąś przeciwwagę powiedzenia współczesnego autora (Denisa de Rougemont), że »miłość przestaje być demonem z chwilą, gdy przestaje być bogiem«, co oczywiście można sformulować w następujący sposób: "Że staje się demonem, z chwilą gdy staje się bogiem«. Ta przeciwwaga wydaje mi się niezbędnym zabezpieczeniem. Jeżeli ją zignorujemy, prawda, że Bóg jest miłością, może podstępnie przyjąć dla nas znaczenie odwrotne: że miłość jest Bogiem. (...) Sądzę, że każdy, kto myślał na ten temat, zrozumie, co Denis de Rougemont miał na myśli. Każda ziemska miłość w swym kulminacyjnym rozkwicie chce rościć sobie prawo do Boskiego autorytetu. Jej głos usiłuje brzmieć jak wola samego Boga. Mówi nam, że nie należy się liczyć z ofiarami, domaga się od nas całkowitego oddania, stara się prześcignąć wszelkie inne pragnienia, insynuuje, że każdy czyn szczerze popełniony "z miłości « jest tym samym legalny, a nawet chwalebny. Wiemy wszyscy, że miłość erotyczna i miłość ojczyzny mogą w ten właśnie sposób usiłować »stać się bogami«. Ale przywiązania rodzinne mogą czynić to samo. I przyjaźń, choć w odmienny sposób, równiež"22.

Rzeczy, które bardziej „przypominają” Boga i przez to domagaja się uznania ich boskości i absolutnej nadrzędności, są z powodu tego podobieństwa łatwiej z Nim mylone, a przez to trudniej jest dostrzec popełniony błąd, czyli że jest się na fałszywej ścieżce. Utrudnia to rozpoznanie, że wcale nie prowadzi ona do „ojczyzny”, ale na przykład do religijnego fanatyzmu, szowinizmu, miłości zaborczej i hołdowania różnym wynaturzeniom. Może to mieć miejsce, gdy samą religię,

22 C.S. Lewis, Cztery miłości, tłum. z ang. M. Wańkowiczowa, PAX, Warszawa 1962, 13-14. 
naród czy miłość uznaje się za najważniejsze, a nie Boga, który jest ponad tym wszystkim.

Wszystko to wskazuje jednak na słuszność zgłoszonego zastrzeżenia, że metoda, jaką Bóg wybrał, aby doprowadzić ludzi do siebie, nie wydaje się najskuteczniejsza, bo nie gwarantuje sukcesu. Byłoby bardziej sensowne - zakładając, że Bóg stworzył człowieka i jego potrzeby - gdybyśmy byli „zaprogramowani” tak, aby trafnie rozpoznawać prawdziwą wartość rzeczy. Ludzie ze swej natury (stworzonej przez Boga) powinni wiedzieć, jak się rzeczy mają, i pragnąć tego, co jest godne pragnienia, a nienawidzić, gardzić, odczuwać niechęć do tego, co jest wstrętne, godne pogardy itd. Ale przecież często tak nie jest. Boski projekt wydaje się nieracjonalny. Nie spotkałem u Lewisa odpowiedzi wprost na ten problem w jego tekstach, poświęconych argumentowi z pragnień. Istnieje jednak odpowiedź, która może być tu przydatna. Jest nią chrześcijańska doktryna o upadku człowieka. Lewis poświęca jej miejsce m.in. w książce Problem cierpienia ${ }^{23}$. Zgodnie z tą doktryną człowiek, niewłaściwie korzystając z wolnej woli, doprowadził do skażenia swojej natury. To sprawia, że popada w różne błędy, a przede wszystkim ma problem z rozpoznaniem Boga jako dobra najwyższego i postępowaniem zgodnym z tym, jak się rzeczy naprawdę mają. Jak to się stało, że doszło do upadku, to już jest inne zagadnienie i przynajmniej chrześcijanie uważają, że istnieje dobra odpowiedź na pytanie o jego przyczynę, która nie obarcza winą Boga. W każdym razie upadek, skażenie natury ludzkiej przez grzech pierworodny, może być dobrą odpowiedzą na problem zabląkania się ludzi na drodze do Boga, także w kontekście rozpoznawania prawdziwej natury ludzkich pragnień.

23 Zob. C.S. Lewis, Problem cierpienia, tłum. z ang. A. Wojtysiak, Wydawnictwo Esprit, Kraków 2010, 83-107. 


\section{ZARZUT DRUGI: PROBLEM PRAWDZIWOŚCI PRZESŁANEK}

Kolejne pytanie odnośnie do omawianej argumentacji, jakie należy postawić, brzmi: Czy przesłanki w rozumowaniu Lewisa na pewno są prawdziwe? Powszechność doświadczenia tęsknoty, o której pisze Lewis, może być uznana za argument na jej wrodzony charakter, tym bardziej, że występuje nawet u osób, zadeklarowanych jako niewierzące. To, że rzeczy tego świata nie są w stanie zaspokoić tego pragnienia, też jest raczej niewątpliwe. Ale czy na pewno jest tak, jak głosi pierwsza przesłanka, że każde wrodzone pragnienie ma przedmiot, który je zaspokaja? Williams przytacza zarzut Beversluisa, który uważa, że jest to słaby punkt w rozumowaniu Lewisa: „Argumenty [Lewisa - P.B.] by uważać, że [Radość ma rzeczywisty obiekt - P.B.] to po pierwsze: Radość jest pragnieniem naturalnym, a po drugie: każde naturalne pragnienie ma rzeczywisty obiekt. Sprawa jest jednak zagadkowa. Skąd Lewis mógł wiedzieć, że każde naturalne pragnienie ma rzeczywisty przedmiot zanim przyjął, że Radość ma taki przedmiot. Mogę prawomocnie twierdzić, że każdy uczeń w klasie oblał test tylko wtedy, jeśli o każdym z nich z osobna wiem, że go oblał. To samo dotyczy naturalnych pragnień" 24 .

Gdyby przyjąć, że rozumowanie Lewisa ma z zamierzenia charakter dedukcyjny, logicznie poprawny czyli niezawodny, to popełniałoby się błąd, polegający na tym, iż jedna z jego przesłanek nie jest pewna. Beversluis wskazuje tu na błędne koło: Lewis wcześniej przyjął, że każde naturalne pragnienie ma przedmiot, który je zaspokaja, i na tej podstawie uznał, że Radość też ma taki przedmiot. Ale właśnie nie jest pewne, czy każde naturalne, wrodzone pragnienie ma przedmiot, który je zaspokaja. Rzeczywiście, gdyby potraktować rozumowanie Lewisa jako ściśle dedukcyjne, to wydaje się, że Beversluis ma rację.

24 J. Beversluis, C.S. Lewis and the Search for Rational Religion, dz. cyt., 19. Zob. też P.S. Williams, C.S. Lewis vs the New Atheists, dz. cyt., 81. 
Są jednak dwa argumenty pozwalające oddalić zastrzeżenie Beversluisa. Po pierwsze, ogólne zdanie, że każde naturalne pragnienie ma przedmiot zaspokojenia, można potraktować jako wniosek rozumowania indukcyjnego, opartego na doświadczeniu. Wniosek taki oczywiście nie jest pewny, jest tylko prawdopodobny. Takie wnioskowania uprawdopodobniające uznaje się jednak za poznawczo wartościowe. Przesłankę pierwszą, że dla każdego wrodzonego pragnienia istnieje przedmiot, który je zaspokaja, można potraktować właśnie jako wniosek tego typu rozumowania. Jak pisał Lewis w cytowanym już fragmencie: „Dziecko odczuwa głód - istnieje pożywienie. Kaczątko chce pływać - istnieje woda. Ludzie odczuwają pożądanie seksualne - istnieje seks". Listę można przedłużać, czyniąc wniosek coraz bardziej prawdopodobnym. Przy takim podejściu wniosek o istnieniu Boga nie byłby pewny, ale prawdopodobny, poznawczo wartościowy. Byłby też dość przekonujący, bo ktoś, kto się z nim nie zgadza, musiałby wyjaśnić, dlaczego przy tak wielu pragnieniach wrodzonych, dla których istnieje przedmiot ich zaspokojenia, akurat to jedno miałoby stanowić wyjątek.

Drugi argument przeciwko zarzutowi Beversluisa pozwala potraktować rozumowanie Lewisa jako logicznie poprawne, a wniosek o istnieniu Boga - jako logicznie konieczny. Problem, jaki tkwi $\mathrm{w}$ zarzucie Beversluisa, ujawnia się $\mathrm{w}$ drugim sformułowaniu argumentu z pragnień. Akcentuje ono ideę absurdalności wszechświata, w którym nie istnieje możliwość zaspokojenia pragnień wrodzonych.

W drugim sformułowaniu argumentacji Lewisa prawdziwość przesłanki nie będzie oparta na wnioskowaniu indukcyjnym, ale na założeniach, których odrzucenie niesie ze sobą konsekwencje, jakich woleliby uniknąć zarówno zwolennicy, jak i wielu przeciwników teizmu. Drugie sformułowanie, przytoczone przez Williamsa, odwołuje się w przesłankach nie tylko do istnienia przedmiotów, zaspokajających wrodzone potrzeby, ale też do absurdalności wszechświata, z którą mielibyśmy do czynienia, gdyby nie istniały przedmioty, zaspokajające wszystkie nasze wrodzone pragnienia: 
1. Jeśli dla każdego wrodzonego pragnienia nie istnieje odpowiadający mu przedmiot, który je zaspokaja, to Wszechświat jest egzystencjalnym absurdem.

2. Wszechświat nie jest egzystencjalnym absurdem.

3. Zatem, dla każdego wrodzonego pragnienia istnieje odpowiedni przedmiot, który je zaspokaja.

4. Ludzie posiadają wrodzone pragnienie Boga (tj. wrodzone pragnienie, którego najbardziej wiarygodna interpretacja głosi, $\dot{z}$ e jest to pragnienie Boga i/lub zaspokojenia, które jest możliwe tylko, jeśli Bóg istnieje).

5. Zatem Bóg istnieje ${ }^{25}$.

Dla niniejszego wywodu kluczowe są dwie pierwsze przesłanki. $\mathrm{Na}$ mocy prawa transpozycji pierwszą z nich można sformułować też jako głoszącą, co następuje: „Jeśli Wszechświat jest egzystencjalnym absurdem, to nieprawda, że dla każdego wrodzonego pragnienia istnieje przedmiot, który je zaspokaja”. Ale czy Wszechświat jest, czy nie jest egzystencjalnym absurdem? Co by to miało znaczyć, że nim jest albo nie jest?

U podstaw wszelkiego ludzkiego myślenia, a już na pewno myślenia uporządkowanego, racjonalnego, którego wzorca upatruje się w nauce, leży założenie o ogólnym porządku, panującym w świecie. W nauce jest ono wyrażane m.in. przez przyjmowanie zasady jednostajności przyrody. Na mocy tej zasady uznaje się, że doświadczenie, przeprowadzone w pewnych określonych, takich samych warunkach, będzie dawać takie same wyniki. Gdyby założyć, że mogą być one dowolne, to poszukiwanie porządku, jakim jest nauka, ale i wszelkie próby poznawcze, nie miałyby sensu. Przyjmuje się więc, że świat nie jest chaosem, lecz Kosmosem, czyli rzeczą dobrze uporządkowaną (zgodnie z greckim znaczeniem słowa кó $\sigma \mu \rho \varsigma$ ). Jest to jednak założenie metafizyczne zarówno w tym sensie, że należy do najbardziej ogólnych twierdzeń o wszystkim, co istnieje, jak i w tym, że nie

25 P.S. Williams, C.S. Lewis vs the New Atheists, dz. cyt., 70-71. 
można go sprawdzić na drodze empirycznej. Aby je potwierdzić, trzeba byłoby dokonać nieskończonej liczby obserwacji wszystkiego, co dzieje się, działo się i będzie się dziać w całym Wszechświecie. Tego oczywiście nie jesteśmy w stanie zrobić. Bez niego jednak sens uprawiania nauki i w ogóle jakiegokolwiek poznania byłby trudny do obrony.

Rozumowanie Lewisa opiera się właśnie na założeniu, że przyroda nie jest chaosem, lecz czymś racjonalnie uporządkowanym. Ten porządek to stan rzeczy wyrażony w przekonaniu, że przyroda nie czyni niczego na próżno. Williams odsyła do następujących słów Lewisa: „Dlatego doszedłem do wniosku, że gdyby człowiek wsłuchiwał się w nie [swoje pragnienia - P.B.] uważnie, i podążał za fałszywymi obiektami, dopóki nie odkryłby ich fałszu, dotarłby w końcu do jasnej i wyraźnej wiedzy, że ludzka dusza została stworzona, by radować się przedmiotem, który nigdy nie zostanie jej w pełni dany. Nie, nie może nawet zostać wyobrażony jako dany w kontekście naszego subiektywnego sposobu istnienia i przestrzenno-czasowego doświadczenia. Pragnienie owo przypomina krzesło, stojące w oblężonym zamku króla Artura - krzesło, na którym jeden tylko mógł zasiadać. Jeśli zaś natura nie czyni niczego na próżno, Ten, który zasiada w owym krześle, musi istnieć" 26 .

Amerykański katolicki apologeta Peter Kreeft zauważa, że gdyby odrzucić to metafizyczne założenie, iż przyroda nie czyni niczego na próżno, to trzeba by przyjąć jako nieuchronną konsekwencję koncepcję Wszechświata jako absurdalnego: „Jeśli przyroda nie czyni niczego na próżno, jeśli przyjąć tę przesłankę, to wynika z niej nieuchronny wniosek. Oczywiście jeśli ktoś za wszelką cenę będzie chciał uniknąć tego wniosku, odrzuci tę przesłankę - jednak za

26 C.S. Lewis, Przedmowa do trzeciego wydania, w: Tenże, Błądzenie pielgrzyma: alegoryczna obrona chrześcijaństwa, rozumu i romantyzmu, tłum. z ang. Z. Kościuk, Oficyna Wydawnicza LOGOS, Warszawa 1999, 16. Zob. też P.S. Williams, C.S. Lewis vs the New Atheists, dz. cyt., 70. 
cenę odrzucenia koncepcji wszechświata, który ma sens, w którym pragnienia i przedmioty ich zaspokojenia odpowiadają sobie"27.

Williams argumentuje, że Wszechświat, w którym wrodzone pragnienia i to, co je zaspokaja, nie pasują do siebie, byłby „absurdalny" w sensie, w jakim o absurdzie mówi egzystencjalizm, szczególnie egzystencjaliści ateistyczni, jak Jean-Paul Sartre czy Albert Camus. Ten drugi w Micie Syzyfa wyjaśniał, że: „Absurd jest przede wszystkim rozdźwiękiem”28. Wspomniani egzystencjaliści postrzegali życie i w ogóle wszystko, co istnieje, jako absurdalne, pozbawione ostatecznych racji, sensu, i mówili także o braku z góry określonego porządku. Stąd wzięła się egzystencjalistyczna idea absurdalności wszelkiego ludzkiego wyboru, gdy nie ma z góry ustalonych reguł, obowiązujących nakazów czy esencji bytów. Odwołując się do kategorii absurdu, Williams, przedstawiając konsekwencję odrzucenia idei o przyrodzie, która nie czyni niczego na próżno, wyjaśnia, że „Wszechświat absurdalny to taki, który nie tworzy koherentnej całości, ponieważ istnieje $\mathrm{w}$ nim rozdźwięk pomiędzy wrodzonymi potrzebami człowieka, a tym, co Wszechświat może zaoferować jako zaspokojenie dla tych potrzeb"29.

Williams cytuje też Spethena T. Daviesa, tłumaczącego znaczenie tezy o absurdzie życia: „Podstawowym założeniem Camus’a było, że życie jest absurdem (...). Pragniemy czegoś w rodzaju Sensu Życia, ale takiego czegoś nie ma (...). Chcemy, aby istniał miły, kochający Bóg, ale taki byt nie istnieje (...). Mamy nadzieję na życie po śmierci, ale ona jest końcem naszego istnienia. Pragniemy jakiegoś wspaniałego,

27 Cyt. za: P.S. Williams, C.S. Lewis vs the New Atheists, dz. cyt., 70 (P. Kreeft, Heaven: The Heart's Deepest Longing, Ignatius, San Francisco 1989, 209).

28 A. Camus, Mit Syzyfa, w: Tenże, Eseje, tłum. z fr. J. Guze, Państwowy Instytut Wydawniczy, Warszawa 1974, 118.

29 P.S. Williams, C.S. Lewis vs the New Atheists, dz. cyt., 70. 
wzniosłego wyjaśnienia życia, historii i istnienia człowieka, ale żadne takie wzniosłe wyjaśnienie nie jest dla nas dostępne"30.

Teza o absurdalności Wszechświata jest tak samo metafizyczną tezą, jak teza mówiąca o istniejącym ogólnym porządku i sensie Wszechświata. Odpowiada idei Wszechświata jako chaosu. Jeśli Wszechświat jest absurdem, to nie ma powodu, aby oczekiwać, że wyniki naszych eksperymentów, przeprowadzonych w takich samych warunkach, będą takie same. Nawet jeśli będą, też będzie to tylko kolejny przykład absurdu. Jeśli przyjąć, że wszechświat jest absurdalny w wyżej wspomnianym sensie, to trudno uzasadnić jakiekolwiek dążenia poznawcze i wysiłki moralne człowieka. Taka jest cena odrzucenia pierwszych dwóch przesłanek w argumencie z pragnień. Jednak racjonalne odrzucanie jakichkolwiek przesłanek i przeprowadzanie jakichkolwiek logicznie poprawnych rozumowań jest również niemożliwe, jeśli wszystko jest absurdem. A zatem jeśli Wszechświat jest absurdem, to nie da się tego nawet prawidłowo stwierdzić. Jest to ta sama konsekwencja, jaką z założenia naturalizmu wyprowadza Lewis w argumencie $\mathrm{z}$ rozumu ${ }^{31}$.

Williams podał drugie sformułowanie argumentu z pragnień, aby wskazać właśnie na problem „absurdalnej” konsekwencji zarzutu Beversluisa: „zarzut Beversluisa zalicza się do tych, za których przyjęcie ceną jest zgoda na koncepcję absurdalnego Wszechświata, którą wyrażał Camus. Jest to filozoficzny koszt, którego wielu myślicieli nie jest gotowych ponieść. (...) jeśli wszechświat miałby być absurdalny, to jak wielkie przekonanie powinien mieć Beversluis co do swojej zdolności racjonalnej oceny argumentów filozoficznych? Czyż nie ma niespójności między z jednej strony uznawaniem, że czyjeś myślenie

30 Cyt. za: P.S. Williams, C.S. Lewis vs the New Atheists, dz. cyt., 70 (S.T. Davis, God, Reason and Theistic Proofs, Edinburgh University Press, Edinburgh 1997, 177).

31 W sprawie Lewisowego argumentu z rozumu zob. C.S. Lewis, Cuda: rozważania wstępne, tłum. z ang. K. Puławski, Media Rodzina, Poznań 2010, rozdział 3. Zob. też P. Bylica, Rozum wobec żałoby, dz. cyt., 136-138. 
jest racjonalne, a jednocześnie przyjmowaniem, że z drugiej strony wszechświat jako całość jest nieracjonalny aż do granic absurdu?”32.

Sam Lewis także przekonywał, że stoimy przed wyborem, iż albo Wszechświat (w tym również my sami) ma sens, albo jest on pozbawiony sensu, a wtedy sensu nie ma ani w nas, ani w żadnej naszej działalności: „Dylemat jest oczywisty. Albo w procesie wszechświata jako całości tkwi sens tak samo, jak w ludzkiej aktywności, albo ludzka działalność jest pozbawiona sensu. To zwykła iluzja, jednocześnie tchórzliwa i arogancka, że możemy ludzką duszę jako jedynie epifenomen wyekstrahować z Wszechświata, rządzonego idiotyczną siłą i jednocześnie żywić nadzieję, że znajdziemy dla niej jakieś miejsce na przedmieściach, gdzie na wygnaniu będzie udawać, że jej roszczenia mają jakąkolwiek wartość. Nie da się mieć obu. Jeśli wszechświat jest pozbawiony sensu, to my też; jeśli jest w nas sens, to jest on nie tylko w nas"33.

\section{ZAKOŃCZENIE}

Argument z pragnień odwołuje się do uczuciowej strony życia ludzkiego, do tego, co nie poddaje się w pełni racjonalnej kontroli. Wcześniej pisaliśmy o możliwym zarzucie wobec tego argumentu, odwołującym się do tego, że oddawanie się zaspokajaniu pragnień może okazać się zwodnicze i prowadzić do odwrotnego celu niż ten, jaki w myśl tego rozumowania był zamierzony przez Stwórcę człowieka. Opieranie się na uczuciach czy nastrojach niesie ze sobą także niebezpieczeństwo, gdy chodzi o aspekt czysto poznawczy. Uczucia, pozbawione asysty i kontroli ze strony rozumu, mogą nie nadawać się jako kryterium ocen poznawczych. Ten problem wskazywany jest $\mathrm{w}$ sporze racjonalizmu $\mathrm{z}$ irracjonalizmem. Zgodne $\mathrm{z}$ dominującym

32 P.S. Williams, C.S. Lewis vs the New Atheists, dz. cyt., 82.

33 Cyt. za: P.S. Williams, C.S. Lewis vs the New Atheists, dz. cyt., 82 (C.S. Lewis, The Personal Heresy: A Controversy, OUP 1965, 29-30). 
w pierwszej połowie XX wieku poglądem na naukę, jest ona działalnością ściśle racjonalną, bo nie ma w niej miejsca na to, co wykracza poza poznanie rozumowe, tj. oparte tylko na faktach i logice. Późniejsza krytyka tego ujęcia poznania naukowego wskazywała na konieczność także innych czynników w nauce, w tym takich, które wcześniej uważano za irracjonalne (jak skłonności względem rozmaitych przekonań metafizycznych) między innymi dlatego, że same fakty i logika nie wystarczają do dokonania rozstrzygnięć naukowych.

Lewis argumentował, że niekiedy kierowanie się samymi uczuciami bez kontroli ze strony rozumu nie jest właściwe dla chrześcijanina. W związku z tym w zgodzie z chrześcijańską tradycją teologiczną przeciwstawiał się rozumieniu wiary jako tzw. ślepej: „Definiuję wiarę jako zdolność utrzymywania przekonania co do czegoś, co wcześniej uczciwie uznaliśmy za prawdę, dopóki przekonujące powody, by uczciwie zmienić zdanie, nie zostaną nam przedstawione” 34 . Pisząc o wierze, miał na myśli „zdolność trwania pomimo zmieniających się nastrojów przy czymś, co twój rozum kiedyś uznał za prawdę"35. Nastroje cechuje zmienność w przeciwieństwie do stałości prawd przyjętych przez rozum: „Teraz, kiedy jestem chrześcijaninem, miewam nastroje sprawiające, że wszystko to wydaje się zupełnie prawdopodobne. Ale kiedy byłem ateistą, miewałem nastroje powodujące, że chrześcijaństwo wyglądało na nieznośnie prawdopodobne (...) jeśli nie nauczysz się »nie poddawać" swoim nastrojom, to nigdy nie będziesz w pełni chrześcijaninem ani ateistą, a jedynie istotą miotaną tam i z powrotem, której przekonania zależą od pogody czy strawności posiłków"36.

Odwołanie do czynników irracjonalnych w argumentacji na rzecz istnienia czegokolwiek wiąże się więc $\mathrm{z}$ zagrożeniem typowym dla

34 Cyt. za: tamże, 56-57 (C.S. Lewis, Religion: Reality or Substitute?, w: C.S. Lewis Essay Collection, 135).

35 Cyt. za: P.S. Williams, C.S. Lewis vs the New Atheists, dz. cyt., 57 (C.S. Lewis, Religion: Reality or Substitute?, dz. cyt., 121-122).

36 Cyt. za: tamże (C.S. Lewis, Religion: Reality or Substitute?, dz. cyt., 123-124). 
oparcia się na jakichkolwiek irracjonalnych podstawach. Zależnie od strawności posiłków czy pogody nasze nastroje i pragnienia mogą się różnić, jak więc miałyby stanowić podstawę do wyciągania racjonalnych wniosków o czymkolwiek? W swej argumentacji, odwołującej się do pragnień, Lewis unika tego zagrożenia, bo nie odwołuje się do zmiennych i przygodnych pragnień, uzależnionych od zmiennych okoliczności, ale do stałego i powszechnego doświadczenia ludzkości, do tego, co wrodzone. Odwołuje się do pragnień w przesłankach swojego rozumowania. Przedstawia więc argumentację, a nie stara się jedynie wywołać wrażenia czy „uwieść” swoich czytelników, i sprawić, że przekonają się do tego, co sprzeczne z zasadami myślenia.

Argumentacja Lewisa, choć opiera się na przesłankach, które odwołują się do uczuciowego aspektu życia ludzkiego, pozostaje argumentacją racjonalną i nadaje się do wykazywania fałszywości naturalizmu oraz prawdziwości teizmu. Przesłanki głoszące: „Jeśli dla każdego wrodzonego pragnienia nie istnieje odpowiadający mu przedmiot, który je zaspokaja, to Wszechświat jest egzystencjalnym absurdem”, oraz: „Wszechświat nie jest egzystencjalnym absurdem”, można streścić w zdaniu: „Natura nie czyni niczego na próżno”. Odrzucenie tych twierdzeń prowadzi do idei Wszechświata jako absurdu. Uznanie wszechświata za absurdalny podważa najbardziej podstawowe założenia poznawcze, przyjmowane przez ludzi. Nie zmienia to faktu, że założenia te mogą być fałszywe. Jeśli jednak wszechświat jest pozbawionym porządku absurdem, to w myśl argumentacji Lewisa nie dałoby się tego poznać, bo warunkiem poznania jest między innymi istnienie porządku, a więc istnienie wszechświata, który absurdem nie jest. 


\section{BIBLIOGRAFIA}

Beversluis J., C.S. Lewis and the Search for Rational Religion, William B. Eerdmans Publishing Company, Grand Rapids 1985.

Bylica P., Argument z pragnień i radości, https://contragentiles.pl/glowne-dzialy/ teizm-chrzescijanski/argumenty-przeciwko-naturalizmowi-i-na-rzecz-istnienia-boga/argument-z-pragnien-i-radosci/, [dostęp 15.9.2020].

Bylica P., Rozum wobec żatoby: argumenty apologetyczne C.S. Lewisa w obliczu dotkliwej straty. Część I. Rozum, Przegląd Religioznawczy (2019)1, 129-143.

Bylica P., Werwętrzna sprzecznośc naturalizmu, https://contragentiles.pl/glowne-dzialy/teizm-chrzescijanski/argumenty-przeciwko-naturalizmowi-i-na-rzecz-istnienia-boga/wewnetrzna-sprzecznosc-naturalizmu/; [dostęp 15.9.2020].

Camus A., Mit Syzyfa, w: Tenże, Eseje, tłum. z fr. J. Guze, Państwowy Instytut Wydawniczy, Warszawa 1974.

Camus A., Upadek, tłum. z fr. J. Guze, Warszawskie Wydawnictwo Literackie MUZA SA, Warszawa 1996.

Davis S.T., God, Reason and Theistic Proofs, Edinburgh University Press, Edinburgh 1997.

Freud Z., Przysztość pewnego ztudzenia, w: Tenże, Kultura jako źródto cierpień, tłum. z niem. J. Prokopiuk, Aletheia, Warszawa 2013.

Kreeft P., Heaven: The Heart's Deepest Longing, Ignatius, San Francisco 1989.

Lewis C.S., Chrześcijaństwo po prostu, tłum. z ang. P. Szymczak, Media Rodzina, Poznań 2002.

Lewis C.S., Cuda: rozważania wstępne, tłum. z ang. K. Puławski, Media Rodzina, Poznań 2010.

Lewis C.S., Cztery mitości, tłum. z ang. M. Wańkowiczowa, PAX, Warszawa 1962.

Lewis C.S., Problem cierpienia, tłum. $\mathrm{z}$ ang. A. Wojtysiak, Wydawnictwo Esprit, Kraków 2010.

Lewis C.S., Przedmowa do trzeciego wydania, w: Tenże, Btadzenie pielgrzyma: alegoryczna obrona chrześcijaństwa, rozumu i romantyzmu, tłum. z ang. Z. Kościuk, Oficyna Wydawnicza LOGOS, Warszawa 1999.

Lewis C.S., Religion: Reality or Substitute?, w: C.S. Lewis Essay Collection: Faith, Christianity and the Church, red. L. Walmsley, HarperCollins, London 2002.

Lewis C.S., The Personal Heresy: A Controversy, Oxford University Press, Oxford 1965.

Lewis C.S., Zaskoczony radościq. Moje wczesne lata, tłum. z ang. M. Sobolewska, Wydawnictwo Esprit, Kraków 2010.

McGrath A., The Intellectual World of C.S. Lewis, Oxford: Wiley-Blackwell 2014. 
Russell B., Autobiografia. Tom II - 1914-1944, tłum. z ang. A. Podzielna, Czytelnik, Warszawa 1998.

Sheiman B., An Atheist Defends Religion: Why Humanity Is Better Off With Religion Than Without It, Alpha, New York 2009.

Święty Augustyn, Wyznania, tłum. z łac. Z. Kubiak, Instytut Wydawniczy PAX, Warszawa 1987.

The Portable Nietzsche, red. W. Kaufmann, Doubleday, New York 1954.

Williams P.S., C.S. Lewis vs the New Atheists, Paternoster, Milton Keynes 2013.

\title{
CLIVE S. LEWIS'S ANTI-NATURALISTIC ARGUMENT FROM DESIRE
}

\begin{abstract}
This article outlines a number of formulations of C.S. Lewis's anti-naturalistic argument from desire. We tackle the problem of the logical validity of this argument and its weak points as characterized in the relevant literature, including objections concerning the deceptive character of irrational factors such as emotions and desires. It is shown that the formulations of Lewis's argument in which the anti-naturalistic conclusion does not deductively follow from the premises can still be considered as adding to our knowledge, when viewed as instances of inductive reasoning. There are also formulations of this argument that can be shown invalid only at the great cost of accepting the premise of the Universe as absurd. Lastly, the objection that Lewis's reference to irrational factors weakens his argument is also rejected.
\end{abstract}

Keywords: Clive S. Lewis; naturalism; theism; argument from desire

\author{
Piotr Bylica \\ Uniwersytet Zielonogórski, Instytut Filozofii \\ (University of Zielona Gora, Institute of Philosophy, Poland) \\ ORCID: https://orcid.org/0000-0001-6668-6170 \\ P.Bylica@ifil.uz.zgora.pl \\ DOI: $10.21697 /$ spch.2020.56.4.09
}

